\title{
The Effect of Softbook on Cognitive and Social Development of 4-5 Years Old Children
}

\author{
Nisa'el Amala, Bachtiar S. Bahri, Wahyu Sukartiningsih \\ Universitas Negeri Surabaya \\ Surabaya, Indonesia \\ amalanisael@gmail.com
}

\begin{abstract}
This study aims to determine the influence of the softbook on cognitive and social-emotional development of 4-5 years old children. This research is included in quantitative research that is quasi-experimental using non-equivalent control group design. The result of the research is a busy book including one instructional media that can facilitate cognitive and socialemotional development of children. Therefore, it can be concluded that there is an influence of the busy book on cognitive and social-emotional development for A-level children.
\end{abstract}

Keywords—softbook; cognitive development; social development

\section{INTRODUCTION}

Education is the main foundation for developing the quality of human resources. Education as a developer attitude and behavior of an individual or a group of people in terms of human maturing in the effort of teaching and training. Broadly speaking, education can be interpreted as a conscious and planned effort to create an atmosphere of learning process, so that children can actively develop their potential skills. Preparation of human resources to create a superior generation should be done since early childhood.

In Permendikbud [1] about the Curriculum 2013 of early childhood education, it has been mentioned that each child's level of achievement level (STPPA) is different according to age. In Permendikbud [2] on the National Standard of Early Childhood is also mentioned each of the scopes of development that must be developed in early childhood they are religious and moral values, physical motor, cognitive, language, emotional social, and art [3]

In Early Childhood (AUD) which is called as a golden period in human development, is the period where the first basic laying process of maturation of six aspects of child development. In these conditions, a required stimulation and conditions are needed as the needs of children, so that the children can grow and develop optimally.

The introduction of the concept form for early childhood is part of the scope of cognitive development that is one important aspect to be developed so that it will impact on the next life. The experience of a child with form is very important because geometry is part of mathematical aspects and part of school readiness nowadays. Knowledge of form also provides an experience as a key to develop the spatial thinking more broadly. However, by achieving a strong conceptual understanding of geometric categories can be continued well into primary school. As stated by Resnick, and friends [4]:

Preschoolers' experiences with shapes are important because geometry is foundational to aspects of mathematics and it is now part of the Common Core for school-readiness. Exposure of shapes also provides experiences that are key to develop spatial thinking more broadly. Yet achieving a strong conceptual understanding of geometric categories can be extended well into elementary school.

Based on this, the child's cognitive development needs to be developed so that children can solve the problems faced by them in the future.

In the theory of knowledge, according to Piaget [5], the child's brain knows how to recognize objects through the senses of the eyes, ears, skin, nose, and mouth directly will show a certain reaction to the environment around the child. But in a deeper thought, Piaget states that knowledge is not only a direct interaction of the senses with reality, but also there must be thought about change. This is important for the children as a part of knowledge building later. Piaget states ([6]) the child's cognitive development is in the preoperational stage. At this stage, children begin to present their world with words and images. Children begin to use primitive thinking and want to know the answers to all the questions. The child's cognitive world is creative, free, and fantastic. Imaginative children work all the time and build their own world mentally. This means the children can begin to describe the situation in their surrounding environment that they see by using spoken language and pictures. The children always want to know the answers of the questions that suddenly arise and try to manipulate the material to satisfy their curiosity.

One of the growing media today is the softbook popularized by Teresita Diana [7] which is presented as a textbook consists of pages with various activities packed in the form of book. The softbook media in its application can develop the aspects of development that exist in early childhood. In early childhood education, softbook media is seen as a creative and innovative new media form to develop the early childhood ability because it can be made based on 
the children needs in the learning process, for example, introducing the symbols of letters, symbols, numbers, and others.

Softbook is an alternative to different learning media in terms of content and materials of manufacture. Based on the content of the book, a softbook has no narrative storyline. The book only displays illustrations of images of various sizes as the theme background. There are also several small thumbnails that can be used in various activities and played according to the child's imagination [8]

The relationship between softbook media and children' cognitive and social development is to play softbook the child is expected to be responsible to obey the rules in sorting numbers and patterns. Children can be patient for a while in waiting their turn to play. Children can work with friends in arranging puzzles inside the softbook and playing the other games on the softbook.

From the results above, the exposure motivates the researchers to conduct a research on the influence of softbook media on the development of children cognitive and social skills.

\section{METHOD}

This study uses a quantitative approach with the type of experimental research, namely to determine whether there is a result of something that was introduced in the sample research.

This research uses an experimental research type with quasi-experimental design (quasi-experiment design) type non-equivalent control group design. The sample in this study is the students of group A RA. AL-Hikmah Turus and RA Al Azhar Ngebrak totaling 114 children. From the description, the selected sample is 114 children divided into two classes namely the experimental class and control class. The experimental class in this study consists of three classes with a total sample of 57 children. Meanwhile, the control class consists of three classes with a total sample of 57 children. The scale used in this study is the rating scale, where there is a scale of 1-4 written with an asterisk. The use of an asterisk is a symbol to show the level of child development achievement as a result of teacher observation.

This research uses data analysis technique with ANOVA and MANOVA at significance level $=0,05$ by using SPSS 22 for windows program. To test the first hypothesis of softbook influence to the cognitive development and second hypothesis that softbook has an effect on the social development, and third hypothesis is softbook use has an effect on to cognitive and social development of early childhood.

\section{Data analysis technique}

According Sugiyono [9] in quantitative research, data analysis is an activity after the research is complete in collecting the necessary data. The activity in analyzing the data is to collect the data based on the variable and respondent type, to tabulate the data based on the variables of all respondents, to present the data of each variable studied, to do the calculation to answer the problem formulation, and the calculation to test the hypothesis that has been proposed.

At the time of the data analysis process, there is an important thing to remember that is to know the exact analysis tool (statistical test). This research uses parametric statistic test. According to Sugiyono, [9] parametric statistics are used to test the population parameters through statistics. In statistics, the parameterized test using statistics (two samples) is called statistical hypothesis testing. Therefore, the hypothesized statistical research is a research that uses a sample. While the sample used in this study should be homogeneous, so it needs to be tested the normality and homogeneity of the sample.

\section{Normality Test}

Normality test is used to determine whether the data condition is normally distributed or not. The condition of normal data distribution becomes lyrical to test hypotheses using statistics. The normality test of the data in this study uses the Kolmogorov Smirnov One-Sample test included in the IBM SPSS Statistics-22 for windows help program. The data is said to be normal if the value sign $>0.05$ then the data is said to be normal, but otherwise if the sign value $<0.05$ then the data said is not normal.

\section{Homogeneity Test}

Homogeneity test aims to determine the similarity between two states or population. The sample is testing its homogeneity by using the Levene's Test. Guideline of decision making is if Levene Statistic: value of significantly smaller than 0,05 then it is said that there is difference of variance between sample group or in other words variance between group is not same and vice versa if significant value bigger than 0,05 hence it can be said that there is no difference variants between groups of samples or in other words variants between groups are the same [9]

\section{Hypothesis Testing}

By answering the problem as expressed in the formulation of the problem, the hypothesis can be tested. Hypothesis testing in this study is using data analysis techniques with ANOVA and MANOVA at the level of significance $=0.05$ with the help of SPSS 22 for Windows program. To test the first hypothesis that is softbook media influence the children' cognitive development and second hypothesis that is softbook media influence the social development of child group A. Both hypothesis use ANOVA analysis technique with the following provisions:

\section{If Fcount $<$ Ftable, then $\mathrm{H} 0 \neg$ accepted and $\mathrm{H} 1$ rejected}

2. If Fcount $>$ Ftable, then rejected and H1 Received 


\section{REFERENCES}

[1] P. Nomor, "146 Tahun 2014 tentang Kurikulum 2013 Pendidikan Anak Usia Dini," Diunduh dari http//dikporaserenganska. blogspot. co. id/2015/03/permendikbud-nomor-137-146-tahun-2014. html pada hari Senin, vol. 5, 2016.

[2] R. I. Permendikbud, "Peraturan Menteri Pendidikan dan Kebudayaan Republik Indonesia Nomor 137 Tahun 2014 Tentang Standar Nasional Pendidikan Anak Usia Dini.” Jakarta: Mendiknas, 2014.

[3] K. E. Darling-Churchill and L. Lippman, "Early childhood social and emotional development: Advancing the field of measurement," J. Appl. Dev. Psychol., vol. 45, pp. 1-7, 2016.

[4] I. Resnick, B. N. Verdine, R. Golinkoff, and K. Hirsh-Pasek, "Geometric toys in the attic? A corpus analysis of early exposure to geometric shapes," Early Child. Res. Q., vol. 36, pp. 358-365, 2016.

[5] E. Y. Rochmah and E. Y. Rochmah, "Psikologi perkembangan." Teras, 2005.

[6] H. HAPIDIN and Y. YENINA, "Pengembangan Model Permainan Tradisional Dalam Membangun Karakter Anak Usia Dini," J. Pendidik. USIA DINI, vol. 10, no. 2, pp. 201-212, 2016.

[7] Nilmayani, "No Title," Pengaruh Pengguna. Media Busy B. Terhadap Kemamp. Membaca Permulaan Pada Anak Usia 5-6 tahun di PAUD Terpadu Filos. Kubu Babussalam Rokan Hilir, 2017.

[8] M. Rohman and S. Amri, "Strategi dan desain pengembangan sistem pembelajaran," Jakarta: Prestasi Pustakaraya, 2013.

[9] P. Sugiyono, "Dr. Metode penelitian pendidikan pendekatan kualitatif, kuantitatif dan R\&D.” Bandung: Alfabeta. 